\title{
Japan's English-medium instruction initiatives and the globalization of higher education
}

\author{
${\text { Heath } \text { Rose }^{1} \text { (D) Jim McKinley }}^{2}$
}

Published online: 22 February 2017

(C) The Author(s) 2017. This article is published with open access at Springerlink.com

\begin{abstract}
This article analyzes a recent initiative of Japan's Ministry of Education, which aims to internationalize higher education in Japan. The large-investment project "Top Global University Project" (TGUP) has emerged to create globally oriented universities, to increase the role of foreign languages in higher education, and to foster global human resources. The TGUP identifies 37 universities: 13 as "top global universities" intended to compete in the top 100 university world rankings and 24 "global traction universities" intended to lead the internationalization of higher education in Japan. Despite the substantial funding behind this initiative, little research has been conducted to evaluate the potential impact of this policy on language planning in higher education in Japan. This paper addresses this gap in its exploration of the TGUP, including key changes from previous internationalization policies. It then presents an analysis of publicly available documents regarding the policy, collected from all 37 of the participant universities. Findings indicate a positive departure from older policy trends and the emergence of flexible, unique forms of English language education in Japan's universities.
\end{abstract}

Keywords Japan · Globalization · Internationalization · English-medium instruction · English language $\cdot$ Higher education

\section{Introduction}

Recent initiatives of Japan's Ministry of Education, Culture, Sports, Science and Technology (MEXT) aim to increase the number of English-medium instructed courses at Japanese universities and to internationalize higher education in Japan. This paper will focus on the

Heath Rose

heath.rose@education.ox.ac.uk

Jim McKinley

j.mckinley@bath.ac.uk

1 Department of Education, The University of Oxford, 15 Norham Gardens, Oxford OX2 6PY, UK

2 Department of Education, The University of Bath, Bath BA2 7AY, UK 
current policy related to the "Top Global University Project" (TGUP). Preliminarily titled the Super Global University Project, the TGUP is a large-investment initiative designed to "enhance the international compatibility and competitiveness of higher education in Japan" and to provide "prioritized support for the world-class and innovative universities that lead the internationalization of Japanese universities" (MEXT 2014). The TGUP has provided funding for 13 "Type A: Top Type" universities, which have been identified as having the potential to become top 100 ranked world universities and 24 "Type B: Global Traction Type" universities, viewed as innovative universities that can lead the internationalization of Japanese society. Policy implementation is still in its infancy; thus, this paper aims to explore the key facets of the project in order to understand the differences between TGUP and the internationalization projects that preceded it. It will also investigate how the TGUP is being operationalized by the participant universities.

The project builds on the foundations of three other project initiatives, which also aimed to provide support for internationalization of Japanese universities including the "Global 30 Project," the "Go Global Japan Project," and the "Re-Inventing Japan Project." The Global 30 Project, which provided funding for 13 Japanese universities and concluded in 2014, focused on building English-medium instruction (EMI) courses and programs. The Go Global Japan Project, launched in 2012 and originally titled the "Project for Promotion of Global Human Resource Development," but rebranded in 2014 and scheduled to conclude at the end of fiscal year 2016, provided funding for 42 universities (Type A: 11 university-wide programs and Type B: 31 faculty/school-specific programs) to develop their international education offerings and to increase the number of Japanese students studying abroad. This came just one year after the Re-Inventing Japan Project, launched in 2011, which was designed to establish collaborative relationships initially with mainly Chinese and Korean universities for the CAMPUS Asia project and North American universities and later with universities in other parts of the world. While Japan's Education Minister has indicated that all policies are interconnected (Shimomura 2013), the Go Global Japan Project has been directly linked to TGUP, as illustrated in Fig. 1, which indicates that it operates as either the foundation for the project or as a second tier to similar globalization aims.

In light of these interconnected policies, this article will explore the main trends related to the internationalization of higher education, specifically focusing on the current largeinvestment project, TGUP. It specifically aims to explore the TGUP objectives in relation to

Fig. 1 Top Global University Project as related to the Go Global Japan Project (MEXT 2014)

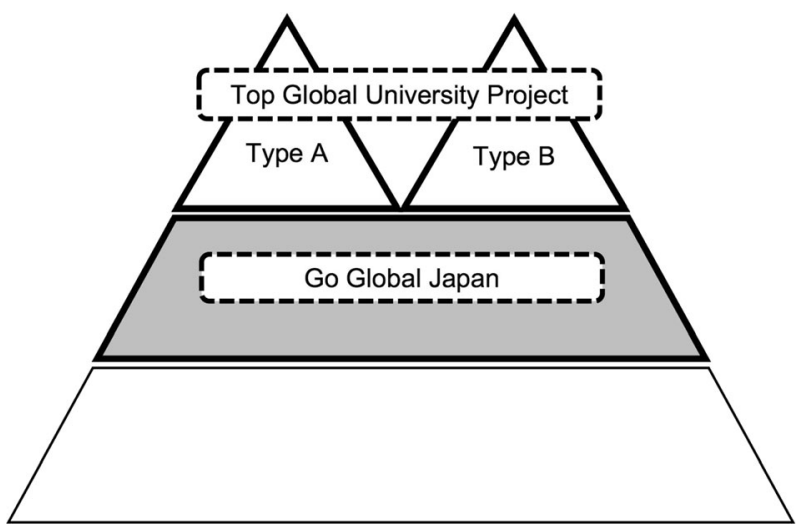


the policies that have preceded it. The paper also examines the relevance of the policy to English language in higher education, including the push for EMI in Japan, which underpins the successful implementation of this project. As Galloway and Rose (2015: 230) note "internationalization of higher education remains a priority for universities worldwide, and movements are inextricably linked with increasing the role of English in the university setting". Japan is no exception to this relationship. After the main issues surrounding English and internationalization are presented, the article will outline the methodology employed, which includes the examination of the policies themselves, in addition to an examination of English-language documents from all 37 TGUP participant universities. The results of this analysis will then be presented before the implications are discussed.

\section{Internationalization of higher education}

An often-used definition of the internationalization of higher education is "the process of integrating an international, intercultural or global dimension into the purpose, functions or delivery of post-secondary education" (Knight 2003: 2). Internationalization is viewed at its worst as an economic ploy to drum up student numbers and tuition and at its best as a way to positively influence universities' global outlook. This section will provide a brief summary of internationalization of higher education, but as it is a topic which has been researched extensively in this journal, readers are encouraged to consult empirical research directly for a detailed overview of the issues noted below.

The negative view of internationalization policies has largely grown out of recent trends in native English-speaking nations to tap into the international market as a means to increase funds flowing to the university and to offset lower domestic tuition or a dwindling lack of public funds. For universities in the UK, international students account for one third of the average university's income from tuition, even though they make up only $13 \%$ of the student body (Brown and Holloway 2008). In 2006, tuition from international students totaled five billion pounds and this is in addition to another five billion pounds that Brown and Holloway estimate to be injected into the UK economy in the form of living expenses. This commercial approach to internationalization has attracted criticism in terms of how universities view their international students. Australia, for example, has been criticized for embracing "a 'no-frills' highly commercial approach to international students and their welfare" (Forbes-Mewett and Nyland 2012: 191). Jenkins (2011: 927) comments "while many universities claim to be deeply international, they are, in essence, deeply national at the linguistic level. And, given that language is such a key component of academic life, their claims to internationalism ring somewhat hollow." This national view of internationalization also extends beyond language, to cultural positioning of education, where Singh (2005: 10) notes that many native Englishspeaking nations view international students as "empty vessels" that need to be filled with Western-oriented knowledge.

A more positive view of internationalization relates to noted benefits that internationalization can have for a university's reputation, research quality, teaching quality, and graduate employability (Delgado-Márquez et al. 2013). Tange and Jenson (2012) observe a difference in perception of internationalization of higher education between native English-speaking nations and many non-English speaking nations, especially those in Europe. Rather than looking at international students as a source of income, Shen (2008: 223) argues that many European universities see internationalization as a way of "attracting and keeping the best brains from around the world to help develop their own knowledge economies." A study by 
Frølich (2006) on the internationalization of higher education in Norway adds support to Shen's assertion by concluding that the moves to internationalize were driven by academic, rather than financial motivations.

Regardless of incentives to internationalize, one matter remains constant - those nations that have benefitted most from internationalization have been native English-speaking nations. Putting aside the debate surrounding the unfairness of benefits afforded to native Englishspeaking nations (e.g., Phillipson 2008), it is clear that English language is highly connected to internationalization. Even in Europe, those universities that have been most successful in attracting international student numbers are the same universities that are able to provide course offerings taught in English - a notion that we will return to when discussing EMI. The European model of internationalization, which places English at its core, coupled with the perceived relationship of English-delivered education resulting in an increase in student numbers, undoubtedly was a large influence on the first of Japan's post-2000 policies that aimed to internationalize Japanese universities.

\section{English-medium instruction}

Another key facet of the TGUP is the notion of EMI, which is defined as an educational system where content is taught through English in contexts where English is not used as the primary, first, or official language. It has been noted that internationalization and EMI in the twenty-first century are inextricably intertwined, as universities turn to Englishization in order to internationalize (Kirkpatrick 2011). Thus, EMI programs have become "commonplace in many institutes of higher education where English is not the native language" (Wilkinson 2013: 3). Recent statistics show that half of the world's international students are learning through English (Ball and Lindsay 2013), indicating the draw of English for attracting students from outside a country's own borders. There is a lack of statistics in Japan, but Europe serves as an example of a possible future for Japan if recent trends continue. In 2007, there were 2400 programs taught in English at 400 mainland European universities and colleges, compared to just 700 such programs in 2002 - a 340\% increase in just 5 years (Wachter and Maiworm 2008). A report by Brenn-White and Faethe (2013) indicates a $1000 \%$ increase in the number of EMI masters' programs in Europe over a period of just 10 years, led mainly by the disciplines of business, economics, engineering, and technology. This trend is happening worldwide (Doiz et al. 2013), and certainly we can see EMI beginning to boom in East Asian nations such as China with the expansion of "internationalization at home" programs (Galloway and Rose 2015: 232). This trend to offer an "international education" in a "domestic" context has also spread to Taiwan in its strive to remain competitive with its larger neighbor (Song and Tai 2007) and also in Japan in the face of current policies that aim to increase its universities' global presence and to attract international students.

\section{Internationalization of higher education in Japan}

Internationalization policy-making has a long history in Japanese education, which has been well documented by a number of researchers such as Seargeant (2008), who discusses the interplay between policy and English language pedagogy. This section will provide a summary of internationalization and education in Japan.

The term kokusaika [internationalization] first appeared in the 1970s and became the go-to expression from the 1980s owed in part to the formation of Prime Minister Nakasone's cabinet 
in 1982. Although there has been continued public rhetoric that kokusaika - which includes an increase in inbound mobility (e.g., see the 1983 "Project on welcoming 100,000 students from overseas") - poses a threat to Japanese identity, national unity, and economic power (Lincicome 2005), it has remained an integral part of Japanese educational policy since this time and has had implications for English language teaching. The term gurobaruka [globalization] is also integral to the description of Japanese higher education. The term first emerged in the late 1990s, and the 2000 report "Prime Minister's Commission on Japan's Goals in the 21 st century" was the first policy document to use this term. The term has been referred to as describing the climate in which Japan has inevitably been affected by, and needs to embrace, globalization (Iwabuchi 2005).

Also around this same time, the Educational Reform Council, which had been established in 1984, was inclined toward "internationalized Japanese education." Their aim was twofold: one, to cultivate patriotism and Japanese identity in an effort to preserve a sense of national identity in an increasingly globalized world; and two, to improve the quality of higher education so as to compete with not only other domestic universities but also foreign universities in global rankings. In addition to the increased competition, Japanese universities also faced two major issues: one, a decreasing domestic youth population; and two, the need to introduce more EMI in the English-dominant world of academia. In 1995, the Short-term Exchange Programs in English were started. It was the education ministry's first funding scheme for national universities to develop an EMI program. Since this time, the numbers of student exchange programs and short-term international (exchange) students has increased. Nevertheless, despite real reasons for improving English language education in Japan, it has been noted that even into the early 2000s, English language education in Japan has suffered from a lack of a coherent language policy (Yamada 2003 cited in Horiguchi et al. 2015). In 2003, the Japanese government proposed a five-year "Action Plan to Cultivate Japanese with English Abilities," which mainly focused on reforming English education in Japanese schools (see Butler and Iino 2005 for a detailed analysis). However, from 2008, Japan saw a string of highprofile policies aimed to internationalize and Englishize higher education in Japan, which had until this point not been a major focus for internationalization policies.

In 2009, MEXT launched the Global 30 Project, which was spearheaded by Prime Minister Fukuda and which aimed to increase the number of foreign students from 124,000 to 300,000 by 2020. The Global 30 Project emerged as a means to attain the objective. After first canceling the project, it was finally enacted by the cabinet in June 2008 under the "basic policies for economic and fiscal management and structural reform" (Burgess et al. 2010). This was followed by the complementary Re-inventing Japan Project in 2011, which focuses on international partnerships, and the Go Global Japan Project in 2012, which focused on building global human resources (i.e., Japanese students with outstanding linguistic abilities, communication skills, and the ability to succeed internationally). Each of these three projects had their strengths and failures and also were subject to criticisms - a point which will be explored further in the policy analysis section of this paper. In light of these criticisms and in the wake of the 2011 Tohoku/Fukushima disaster, there was concern that the projects - particularly the Global 30 Project - would be unable to meet their mobility objectives. Even though a number of participant universities with well-established English-medium offerings were on target to meet the Global 30 objectives at the time of the conclusion of the project in 2014, MEXT refocused away from English-only programs and more toward general globalized education. The shift recognized potential strengths of EMI programs launched by the original 13 selected Global 30 universities (as well as the advances made in the Go Global Japan and Re-Inventing Japan projects), but expanded MEXT's initiatives. 
Japan's then Education Minister, Hakubun Shimomura, who was also the minister in charge of the Education Rebuilding Implementation Council, focused on university reform and growth of global human resources. The Council finalized a set of proposals in May 2013 titled "University Education and Global Human Resource Development for the Future." The proposals focused on the enrichment of Japan's global competitiveness and revitalization. To achieve this, the Council highlighted the need for Japanese universities to comprehensively internationalize the educational content of their programs and academic environment and foster future, active global leaders.

\section{The study}

The study aimed to explore the following research questions:

1. What are the key differences between TGUP and the three internationalization of higher education projects that preceded it regarding their English language education initiatives?

2. How is the TGUP being interpreted into implementation by the participant universities on their international-facing websites?

Each question dealt with a different level of policy implementation. The first question examined the policy from a top-down perspective, as dictated by MEXT. The second question examined how universities aimed to implement the policy, exploring how these plans manifested into practice across faculties and courses.

In the first phase of the research, in order to respond to research question one, the official press releases and policy documents concerning the TGUP and preceding projects were analyzed. The wording of the documents was coded according to how they positioned key concepts related to internationalization including, but not limited to, internationalization of faculty, student mobility, national identity, medium of instruction, English language, global competitiveness, and target student numbers. Analysis of the data aimed to highlight shifts in scope and aims of the TGUP compared to previous policy and to analyze changes in rhetoric toward the role of English language in the internationalization of higher education in Japan. To collect further data on the implications of the TGUP policy, in research phase two, public documents from each of the 37 selected universities for TGUP were analyzed in terms of how their role in the project was outwardly communicated. Data were collected via the websites of each of the universities in order to understand how the universities viewed their involvement in the project and how the implications of TGUP manifested in the universities' strategic plans, mission statements, and public identity. These documents were also coded and analyzed according to key concepts, with a particular focus on English language education. In total, more than 21,000 words of documentation were collected.

\section{Limitations}

Only documents in English were used for analysis, as these were the documents the universities released for international readership. Although inclusion of Japanese language documents was originally considered, the final decision to exclude them from our sample was based on a number of factors: first, as many English documents were translations of Japanese documents the inclusion of both would equate to doubling much of the data; second, our research questions focused on the public face of policy toward an international community, and Japanese language documents were seen as forming part of a university's domestic face; 
third, inclusion of documents only in English, which was the language used for analysis and publication, evaded the issue of translation error, which sometimes sees the inclusion of incorrect data leading to false inferences. There were also practical considerations, such as the cost of professional translation of policy documents into English for analysis, which were beyond the remit of the current study. By excluding Japanese language documents, we acknowledge a limitation in this study; detailed information regarding these policies has been made available in Japanese, and these are not included in the final data set. We also acknowledge that English and Japanese versions of similar documents may differ, and this has also not been captured in the study. Thus, an exploration of such differences could form the basis of a future investigation. This limitation also lends itself to a future replication study of Japanese language policy documents to investigate whether the same results are found.

\section{Coding}

In order to code the volume of data collected, the researchers used qualitative data analysis software (NVivo 10). The methodology used to analyze data follows the practices of "qualitative text analysis" (Kuckartz 2014), which broadly follows the same tradition as "qualitative content analysis" (Mayring 2000). Within the method of qualitative text analysis, coding of the data was conducted along lines of "thematic text analysis" (Kuckartz 2014), utilizing a mixture of concept-driven and data-driven categories (Schreier 2014). Following the typical methodology of qualitative text/ content analysis (see Schreier 2014), a coding frame was established based around central themes; these were trialed within the data, evaluated, and modified as new themes emerged from the data. The data went through two stages of main coding, the first being used to broadly code and establish central themes and the second involving more refined coding and categorization. This detailed analysis gave a contextualized overview of how TGUP was being interpreted and implemented by the participant universities.

The findings are organized in response to the research questions and each phase of data collection. First, we present a comparative analysis of the four recent internationalization of higher education projects including a focus on their language planning implications. This is followed by an analysis of the positioning of TGUP in public documents of the selected universities, including an analysis of the implications of TGUP for language planning.

\section{Comparative analysis of Japan's internationalization projects}

The four recent internationalization projects were developed in response to Japan's decreasing global competitiveness. According to data from the IMD World Competitiveness Center and the World Economic Forum, Japan's global competitiveness score has been on the decline. There are well-known causes, such as the decreasing birth rate, an aging population, continuous economic recessions, and the 2011 nuclear disaster. First, each of the three preceding policies will be outlined in general, before the TGUP is analyzed against the backdrop of these three policies according to emerging themes underpinning the policy objectives, the direction of mobility, and treatment of language. 


\section{Global 30}

The Global 30 Project emerged as a means to attain the objective of increasing international student numbers in Japan. In 2009, 13 universities were chosen and given financial support of between 200 million and 400 million yen per year over the next 5 years so they could improve their conditions and faculties to accommodate an increased number of foreign students. Central to this policy was the establishment of English-medium programs aimed at an international student market. Each university had its own specific target goals to reach by 2020 that focused on increased numbers of international students and academic staff.

Several criticisms were raised in consideration of the practicality of the Global 30 Project (Burgess et al. 2010; Hashimoto 2013). One particular objective that was overlooked was that foreign students were expected to experience Japanese culture and language. However, due to the fact that all of the classes in this project were conducted in English and some courses excluded Japanese local students, opportunities to learn Japanese culture and language were rare. Furthermore, in some universities such as Tohoku University and Kyoto University, local Japanese students did not have the right to apply for the Global 30 initiated courses (Hashimoto 2013). These approaches clearly hampered accomplishing the objective.

Furthermore, MEXT was accused of using the initiative to further Japan's dualism (Japanese and the Other) and for continuing to push a national identity agenda disguised as internationalization (Hashimoto 2013), which had also been an aim of the earlier kokusaika policy. The concern is that "Otherness" causes a divide between Japanese and international students, who under the Global 30 Project were often enrolled in separate courses. Hashimoto (2013: 18) likened the divide to the belief in Japan that "bilingualism belongs to foreigners." As for cases where Japanese local students were enrolled in EMI courses, some experienced great difficulty, ultimately dropping such courses and even the university altogether (Selzer and Gibson 2009). This sink-or-swim situation they confront is so problematic that adequate language support for enabling Japanese students to deal with English-medium courses successfully is desperately needed (Echevarria and Graves 2006).

\section{Re-inventing Japan}

As the Global 30 Project was underway, in 2011, MEXT rolled out another internationalization project: the Re-inventing Japan Project, which focuses on two-way student mobility and concern for the need of global human resources. The Re-inventing Japan Project is an ongoing annual fund designated for establishing collaborative relationships with strategic partner universities in particular geographic locations that are looking to increase their own numbers of international students and study abroad (outbound) students. There are two categories. One is for programs to form consortia with universities in Japan and around the world. The second category focused on the $40 \%$ decline in Japanese student numbers enrolled in universities in the USA (Imoto 2013) and provides funding for partnerships through programs such as Student Exchange Nippon Discovery (SEND). Each year of the project, a region is targeted: in 2011 it was Japan/China/South Korea's "CAMPUS Asia," in 2012 it was ASEAN countries, in 2013 it established the "ASEAN International Mobility for Students" (AIMS) program, in 2014 it was Russia and India, and in 2015 more than 11 collaborative Japanese university projects involving more than 20 Japanese universities established partnerships with more than 60 universities in Latin America, the Caribbean, and Turkey. 
In terms of language objectives, the policy highlighted the importance of increasing domestic students' proficiency in English in order to study abroad. It also placed a smaller emphasis on student and faculty development in languages other than English. Similar to the Global 30 Project, the policy also highlighted the need for incoming students to learn Japanese language and culture. However, the Re-inventing Japan Project puts emphasis on both inbound and outbound student mobility, probably due to this objective being at the core of the Global 30 Project, which was running concurrently. The policy, instead, highlighted the need to "improve global competitiveness through global human resources," thus putting the focus of developing the domestic student body to meet global needs through internationalization. Therefore, on this point, the policy differed greatly from Global 30, in its focus on the recruitment of international students to contribute to institutional collaborations (collaborative education programs) between Japanese universities and universities abroad focusing on twoway student mobility.

\section{Go Global Japan Project}

The Go Global Japan Project was initiated in 2012, one year after the launch of the Reinventing Japan Project. Originally titled the "Project for Promotion of Global Human Resource Development," it was rebranded in 2014 and scheduled to conclude at the end of fiscal year 2016. The one-time project was developed in response to concerns about the continuing decrease in the number of Japanese students studying abroad and focused on preparing "global talent" or "global human resources." In this respect, the Go Global Japan Project focused on outbound mobility from Japan (study abroad of Japanese students) in terms of the internationalization of the Japanese student body. However, while the Re-inventing Japan Project focuses each year on a key collaborative market, the Go Global Japan Project was more general in its objective to develop global citizens.

The project began in the wake of one of Japan's worst disasters, the Tohoku earthquake and tsunami and subsequent fallout from Fukushima, that saw an increase in inward-looking domestic students, the return of many Japanese students studying abroad, and a drop in numbers of international students wanting to travel to Japan (Sugimura 2015). The project provided funding to a total of 42 universities: 11 "Type A" universities that received 140-260 million yen and were required to enhance university-wide programs for the promotion of study abroad programs and outbound mobility of Japanese students and 31 "Type B" that received 120 million yen to support faculty/school-specific programs to promote study abroad programs to the university as a whole, creating some good practices of outbound mobility.

The aim of the project was for participant universities to develop their international education offerings and to increase the number of Japanese students studying abroad. Interestingly, the policy did not specifically call for the establishment of English-medium instructed programs or the development of English language programs, but instead emphasized the need to "internationalize" the universities. However, in most cases, this objective was interpreted to mean to "Englishize" the universities and their programs. One difference between this policy and Global 30, however, was that funds were used to develop outbound mobility programs, including making innovations to existing programs. This was in stark opposition to Global 30 , which targeted the establishment of new programs squarely aimed at the international student market. 


\section{TGUP compared to preceding policies}

This section aims to explore the TGUP objectives in relation to the three preceding policies. Table 1 was generated to show the development of, and difference between, the objectives of each project, with consideration given to how each project impacted English language planning in not only participant universities but also Japanese higher education in general.

In terms of mobility, the TGUP sees a return to an emphasis of inbound mobility flows of international students and international faculty, thus mirroring the Go Global Japan Project's objectives to internationalize by attracting global human resources. The TGUP clearly has a more nuanced understanding of its internationalization objectives compared to the Global 30, which was focused squarely on increasing the number of international students; the objectives of the Global 30 were somewhat untenable as they focused on developing EMI programs without sufficient support for such programs. The conclusion of the Global 30 was timed to coincide with the launch of the TGUP, which overlaps with the objectives of increasing the number of international people on Japanese university campuses, maintaining very ambitious numerical targets (goals) of international students and faculty members to be selected. While the focus remains on increasing the number of foreign students, it aims to achieve this growth through the development of existing programs that play to each university's context. There is also a focus on increasing the number of international staff, with a push for universities to create more tenure-track positions for foreign faculty. This could include foreign-trained Japanese nationals as well as foreign staff. The idea of increasing international faculty and students was significant and was commented on by Japanese Prime Minister Shinzo Abe, who said at a 2014 conference of university leaders from the UK and Japan, "the number of foreign students at a university will define its success" (Taylor 2014).

Importantly, the TGUP also maintains an emphasis on outbound mobility in its goals to internationalize their domestic student body as well, thus purporting similar objectives to the Re-inventing and Go Global Japan projects. The outward mobility initiatives of the Reinventing Japan, the Go Global Japan, and Top Global University projects all focus on increasing the number of domestic Japanese students studying abroad and on developing global human resources with strong ability with languages and communication and with a strong sense of leadership and the ability to succeed internationally. While the Re-inventing Japan Project is focused specifically on establishing partnerships with foreign universities that would host Japanese university students and send their students to Japanese universities, the Go Global Japan Project was more concerned with the latter objective focusing on "global talent." As a result, these two projects have targeted English language skills development of domestic students to prepare them for study abroad and for playing active roles as future global leaders.

The TGUP has been a cumulative effort, essentially combining the objectives of all three prior established internationalization projects. In terms of English language education, it targets both English language skills development of domestic students and EMI. While the policy is worded to include all "foreign languages," the finer details of the policy point to English as the main language driving the internationalization of higher education in Japanespecially in terms of language education and English-taught domestic programs aimed at both the international and local market. Thus, although not explicitly stated in the policy, implementation of the policy in Type B universities will likely manifest in an increase in the presence of English at the institutions, as well as an increase in programs taught through the medium of English. 
Table 1 Comparison of internationalization of Japanese higher education policies

\begin{tabular}{|c|c|c|c|c|}
\hline & Global 30 & Re-inventing & Go Global & TGUP \\
\hline Years active & 2009-2014 & 2011-ongoing & $2012-2016$ & 2014-2023 \\
\hline $\begin{array}{l}\text { Number of } \\
\text { universities }\end{array}$ & 13 & $\begin{array}{l}\text { Hundreds worldwide } \\
\text { have been } \\
\text { involved; only the } \\
\text { Japanese } \\
\text { universities are } \\
\text { funded }^{\text {a }}\end{array}$ & 42 & 37 \\
\hline $\begin{array}{l}\text { Objective: } \\
\text { students }\end{array}$ & $\begin{array}{l}\text { To accept } 300,000 \\
\text { international } \\
\text { students; smaller } \\
\text { emphasis on } \\
\text { Japanese students } \\
\text { studying abroad }\end{array}$ & $\begin{array}{l}\text { To encourage and } \\
\text { support Japanese } \\
\text { students studying } \\
\text { abroad; to foster } \\
\text { globally-active hu- } \\
\text { man resources; } \\
\text { smaller emphasis } \\
\text { on accepting for- } \\
\text { eign students }\end{array}$ & $\begin{array}{l}\text { To overcome younger } \\
\text { generation's } \\
\text { "inward tendency"; } \\
\text { to foster global } \\
\text { human resources to } \\
\text { succeed in the } \\
\text { global field }\end{array}$ & $\begin{array}{l}\text { To increase } \\
\text { international } \\
\text { students and study } \\
\text { abroad exchanges; } \\
\text { generating } \\
\text { graduates as active } \\
\text { global leaders }\end{array}$ \\
\hline $\begin{array}{l}\text { Objective: } \\
\text { partnerships }\end{array}$ & $\begin{array}{l}\text { To establish overseas } \\
\text { offices for } \\
\text { recruitment; seek } \\
\text { cooperation for } \\
\text { study abroad }\end{array}$ & $\begin{array}{l}\text { To establish } \\
\text { collaborative } \\
\text { partnerships with } \\
\text { universities around } \\
\text { the world }\end{array}$ & $\begin{array}{l}\text { To enhance ties } \\
\text { between nations }\end{array}$ & $\begin{array}{l}\text { To increase } \\
\text { international } \\
\text { collaboration }\end{array}$ \\
\hline $\begin{array}{l}\text { Objective: } \\
\text { faculty }\end{array}$ & $\begin{array}{l}\text { To attract high quality } \\
\text { researchers and } \\
\text { teachers from } \\
\text { abroad }\end{array}$ & $\begin{array}{l}\text { Small emphasis on } \\
\text { development of } \\
\text { faculty proficiency } \\
\text { in other languages }\end{array}$ & $\begin{array}{l}\text { To internationalize } \\
\text { faculties and } \\
\text { schools }\end{array}$ & $\begin{array}{l}\text { Increase international } \\
\text { faculty or } \\
\text { foreign-trained fac- } \\
\text { ulty }\end{array}$ \\
\hline $\begin{array}{l}\text { Objective: } \\
\text { language or } \\
\text { EMI }\end{array}$ & $\begin{array}{l}\text { To increase the } \\
\text { number of } \\
\text { English-only } \\
\text { courses; to provide } \\
\text { Japanese language } \\
\text { and culture classes } \\
\text { to foreign students }\end{array}$ & $\begin{array}{l}\text { For Japanese students } \\
\text { to learn other } \\
\text { languages (English } \\
\text { in most cases of } \\
\text { implementation); } \\
\text { for foreign students } \\
\text { to study Japanese } \\
\text { language and } \\
\text { culture }\end{array}$ & $\begin{array}{l}\text { To internationalize } \\
\text { university } \\
\text { education in Japan; } \\
\text { each selected } \\
\text { university was } \\
\text { required to set the } \\
\text { goals of students' } \\
\text { English proficiency } \\
\text { test scores (which } \\
\text { were strictly } \\
\text { observed by } \\
\text { MEXT), such as } \\
\text { TOEFL or TOEIC } \\
\text { scores }\end{array}$ & $\begin{array}{l}\text { To increase courses } \\
\text { taught in a foreign } \\
\text { language (with } \\
\text { focus on English); } \\
\text { increase student } \\
\text { proficiency in } \\
\text { foreign languages; } \\
\text { provide Japanese } \\
\text { language courses } \\
\text { for foreign students } \\
\text { and researchers; } \\
\text { write syllabuses in } \\
\text { English and other } \\
\text { university } \\
\text { information }\end{array}$ \\
\hline $\begin{array}{l}\text { Objective: } \\
\text { competitive- } \\
\text { ness }\end{array}$ & $\begin{array}{l}\text { To improve global } \\
\text { competitiveness } \\
\text { via EMI and } \\
\text { increasing student } \\
\text { numbers }\end{array}$ & $\begin{array}{l}\text { To improve global } \\
\text { competitiveness } \\
\text { through global } \\
\text { human resources }\end{array}$ & $\begin{array}{l}\text { To improve global } \\
\text { competitiveness } \\
\text { through global } \\
\text { human resources }\end{array}$ & $\begin{array}{l}\text { To improve global } \\
\text { competitiveness } \\
\text { through university } \\
\text { rankings (Type A) } \\
\text { and university } \\
\text { internationalization } \\
\text { (Type B) }\end{array}$ \\
\hline $\begin{array}{l}\text { Mobility } \\
\text { direction }\end{array}$ & $\begin{array}{l}\text { Emphasis on inbound } \\
\text { mobility }\end{array}$ & $\begin{array}{l}\text { Emphasis on two-way } \\
\text { (inbound and out- } \\
\text { bound) mobility }\end{array}$ & $\begin{array}{l}\text { Emphasis on } \\
\text { outbound mobility }\end{array}$ & $\begin{array}{l}\text { Inbound and } \\
\text { outbound mobility } \\
\text { for the promotion } \\
\text { of comprehensive } \\
\text { internationalization } \\
\text { of leading } \\
\text { universities }\end{array}$ \\
\hline $\begin{array}{r}\text { Impact on } \\
\text { English }\end{array}$ & $\begin{array}{l}\text { Aggressive } \\
\text { establishment of }\end{array}$ & $\begin{array}{l}\text { Increase in domestic } \\
\text { English language }\end{array}$ & $\begin{array}{l}\text { Even greater increase } \\
\text { in domestic }\end{array}$ & $\begin{array}{l}\text { EMI programs are a } \\
\text { result of policies }\end{array}$ \\
\hline
\end{tabular}


Table 1 (continued)

\begin{tabular}{|c|c|c|c|c|}
\hline & Global 30 & Re-inventing & Go Global & GUP \\
\hline $\begin{array}{l}\text { language } \\
\text { planning }\end{array}$ & $\begin{array}{l}\text { EMI programs in } \\
13 \text { universities } \\
\text { across Japan, } \\
\text { which impacts } \\
\text { hiring of } \\
\text { English-speaking } \\
\text { faculty and admin- } \\
\text { istrative staff }\end{array}$ & $\begin{array}{l}\text { education; there is } \\
\text { a need to ensure } \\
\text { Japanese students } \\
\text { are prepared to use } \\
\text { their English skills } \\
\text { in study abroad } \\
\text { contexts }\end{array}$ & $\begin{array}{l}\text { English language } \\
\text { education } \\
\text { (recognition of } \\
\text { weaknesses of EMI } \\
\text { programs, but EMI } \\
\text { programs continue } \\
\text { under this policy) }\end{array}$ & $\begin{array}{l}\text { that aim to increase } \\
\text { "international } \\
\text { education"; } \\
\text { "foreign language } \\
\text { education" (in } \\
\text { practice, English) a } \\
\text { priority; provision } \\
\text { of information in } \\
\text { English has } \\
\text { implications for } \\
\text { administrative staff }\end{array}$ \\
\hline
\end{tabular}

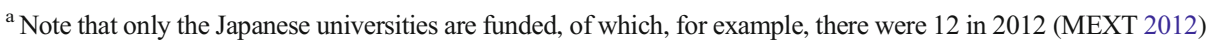

Finally, the TGUP expands on the objectives of the previous three policies in its focus on research excellence. The separate objectives of Type A and Type B universities emphasize the role of research in the internationalization of Japanese universities. While Type B universities are charged with the internationalization of Japanese society (and campuses), Type A universities are charged with the aim to become "top 100 ranked world universities." Thus, Type A universities are required to reach their objectives through different processes, which are stated to include the attraction of top international researchers, in addition to allocating funds for student mobility and curriculum innovation. While Type A universities are not explicitly required to focus on the Englishization of the university, current trends would indicate this to be a side effect of its research objectives. English language currently holds a near monopoly of published academic research (Galloway and Rose 2015; Montgomery 2013); thus, it plays a central role in increasing the research standing of Type A universities.

\section{Results of policy implementation and document analysis}

In the second phase of the research, publicly available documents on the websites of all 37 universities of the TGUP were coded and analyzed according to key themes. In total, more than 21,000 words of documentation were collected from university public websites and coded. The researchers first employed open coding to identify and agree on set nodes and then used these nodes to code the documentation. The final list of nodes included the following:

- Faculty internationalization

- Global profile/reputation

- University ranking

- Research output

- Partnerships

- Internationalization (General)

- Creation and retention of global graduates/human resources

- Attracting international students

- English language education 
- International collaboration

- Japanese language and studies

Three additional nodes had been placed on the original list, but were later removed due to a lack of coverage across source material. These were

- English-medium instruction, which was a key term in previous policy documents such as the Global 30, but notably absent in explicit descriptions of TGUP documents;

- Curriculum internationalization, a key concept in previous policy documents that sought to create new programs aimed at international students, but also somewhat absent in TGUP documentation across most sources;

- Faculty development, as source material tended to focus on the recruitment of faculty with international experience, rather than the development of existing faculty

In analysis of the data, research output was the most heavily coded node in the documentation and was evident in source material from 30 of the 37 universities, with 85 references to research in total. For example, Chiba University stated it would use the TGUP to launch initiatives to make it "a university promoting world leading education and research." Other universities such as Meiji University claimed to be "making great strides in innovating education and research at the university." Many of the Type A universities linked research output to their plans to increase the world ranking of the university. Others, such as Osaka University, indicated clear avenues where money would be spent to achieve these aims, such as increasing their current 22 labs to 100 labs in an effort to attract overseas professor-level researchers. While research output was at times linked to international collaboration and attracting international faculty, the role of English in this collaboration was not explicitly stated in the source documentation.

In terms of English language planning, only 17 of the 37 universities explicitly discussed the role of English in the university's plans to internationalize, which marks a difference in the positioning of English as the catalyst for internationalization in the previous policy. Nevertheless, many universities did discuss the development of programs taught in English, but unlike the Global 30 initiative, these courses were often positioned as providing domestic students with opportunities to learn through English alongside international students. Some universities such as Sophia University had clear figures to increase "English-conducted classes to $22.8 \%$ from 13.6\%." Others such as Hiroshima University sought to increase "foreign language taught courses" to $50 \%$ across the university.

Two universities, Akita International University and Chiba University, seemed to conflate English language education and the native English speaker, describing initiatives such as "English villages," mandatory study abroad requirements to English-speaking universities, and small group discussion classes "led by a native speaker." Initiatives such as these were in stark contrast to how English was positioned by other universities, of which Rikkyo University was perhaps the most illustrative example. This university explicitly utilized English as a means to expand courses, double-degree programs, and to implement "international cooperative graduate programs in English." While at first glance, this might be somewhat reminiscent of the Global 30 objectives, a closer examination revealed a more global orientation to these courses. Rather than linking English-taught courses with native speaker-led education, the university stated it was specifically targeting students from Africa, the Middle East, and ASEAN nations, and some of the double-degree options were offered in partnership with non-English speaking 
regions of the world, such as a Masters of International Business offered in partnership with an EMI university in France. English was positioned as an educational lingua franca, to not only use abroad but by Japanese students on their own campus, both in and outside of class, such as in international dormitories.

Some universities such as International Christian University and Tokyo University emphasized the use of English alongside other languages as part of the students' bilingual or multilingual educational context. Tokyo University stated that while courses throughout their curriculum are available in English, "high levels of teaching and research are carried out in Japanese"; the university also emphasized courses in "languages other than English." International Christian University emphasized their bilingual education tradition in English and Japanese, stating that they aimed to round out not only the English education of many of their domestic students but also the Japanese language education of those students who had come from internationally based high school systems. Tokyo University of Foreign Studies shared a similar sentiment in arguing that the TGUP helped extend its current plans to "train multilingual global students."

In an effort to summarize the relationships found in the coding, a cluster analysis was performed within NVivo 10. This technique uses the Pearson correlation coefficient as a similarity metric to cluster nodes according to coding similarity. This technique generates an easily understandable qualitative result from qualitative data using a quantitative data analysis technique. The cluster analysis explores similarities and differences across nodes and is intended as an exploratory tool rather than for drawing definitive conclusions. The clustered nodes are shown in Fig. 2.

Here, we can see a possible relationship, in terms of the nodes research output, internationalization, and increase ranking sharing a similar coding space. This relationship was verified by data in which universities viewed an increase in research output as the major means to increase their university's global rankings. Numerous excerpts from the data illustrated how these codes intersected, such as the following statement from Waseda University, which stated that it aims to "produce 100,000 global leaders within 10 years and rank among the world's top 100 universities in 18 research areas within 10 years." This example showcases the importance of research goals to ranking outcomes and also shows how concepts of the creation of global graduates and the creation of a university global profile also interplay with both research output and rankings.

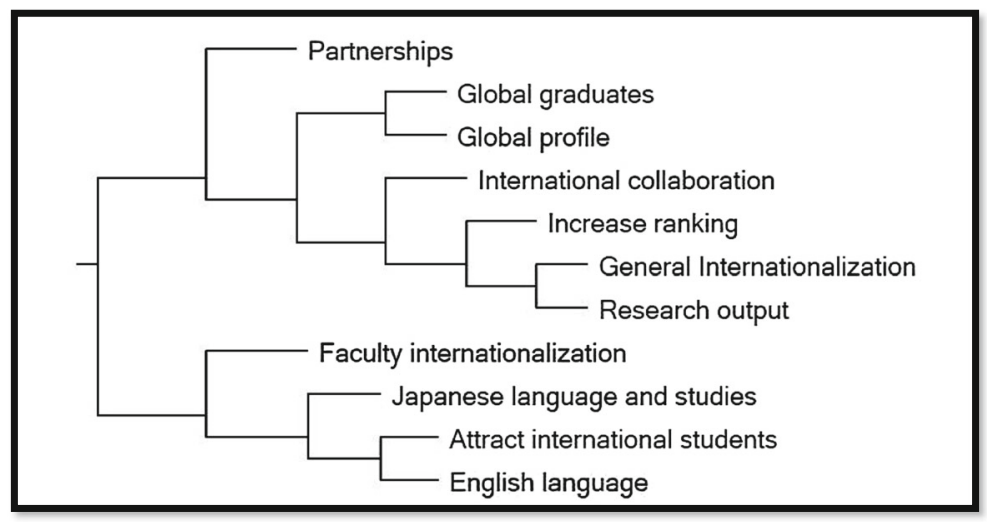

Fig. 2 Nodes clustered by coding similarity 
The cluster analysis also suggests a strong potential relationship between English language and the attraction of international students, which then interplayed with Japanese language and studies and faculty internationalization. Results from phase one of this study have already shown a strong tradition in higher education policy to use English language-taught courses as a means to attract international students. While this link was not as clear in the TGUP data, notions of English language and international students were clearly intersected. For example, Hiroshima University states an aim to increase international student numbers from 1678 to 3600 and to also increase the percentage of courses taught in "a foreign language" to $50 \%$. As the TGUP policy documents indicated, although the term "foreign language" is used in policy, the foreign language is almost entirely English in implementation. Nevertheless, no instances that directly linked the purpose of English-taught courses to attract international students were found in the data, marking a stark departure from the rhetoric of the Global 30 and Go Global Japan policies.

Similarly, while analysis indicated a positive correlation of word similarity between the nodes of faculty internationalization and English language, faculty internationalization was often discussed independently of English language requirements. For example, Waseda aimed to recruit "world-class faculty" from "around the globe." Others stated specific targets such as Hiroshima University's target of 53\%, Kyoto University's target of 100 new international faculty members, and Osaka University's target to "double the number of outstanding international faculty members within 3 years." While these universities did not specifically state that international faculty meant "English-speaking" international faculty, with the growing emphasis on English-taught programs and the importance placed on research output, one criterion in hiring these faculty may be their ability to teach and publish in the English language.

In summary, in our analysis of policy documentation, we found that universities had interpreted the TGUP policy in accordance to the top-down policy delivered from MEXT. Funds from TGUP were being implemented to increase the quality of research at the university and to create a more global university environment, through internationalization of programs, faculty, the student body, and student experiences. While only some of the participating universities explicitly discussed the role of English in their internationalization plans, indicating a different positioning of English as the stimulus for the previous policy, many universities highlighted the development of programs taught in English.

\section{Discussion}

The analysis of the TGUP policy documents indicates a more positive framing of internationalization in contrast to the three preceding policies. The much criticized Global 30 policy rationalized its increase in EMI programs for the purposes of increasing student numbers, thus mirroring criticisms of internationalization of other nations such as Australia that took a commercial approach to internationalization (Forbes-Mewett and Nyland 2012). The newer TGUP has considerably lessened the rhetoric of "driving up student numbers" and increased rhetoric surrounding a need to internationalize for academic, social, and integrative purposes, thus mirroring the stance of European nations that seek internationalization for academic incentives (Frølich 2006) or as a means to develop a more international knowledge economy (Tange and Jensen 2012). The stance of the 37 universities involved also perpetuate this ideal in mission statements and objectives, where they positioned internationalization as a means to 
integrate their university into a global field and to create global human resources from their graduates.

While the role of EMI and domestic English language education in this internationalization process has been downplayed in the main objectives of the TGUP, the English language is still clearly intertwined with achieving its objectives. The documents of the 37 universities pointed to aims to increase English-taught courses and to emphasize English and foreign language education for their students. Previously, it has been argued that Japan's internationalization policies conflated the terms globalization with Englishization (Phan 2013), and it is undeniable that Englishization is seen as a necessary part of internationalization in TGUP. We recognize that English is not only a prominent feature in Japanese society (Seargeant 2011) but also concur with Kirkpatrick (2011) that Englishization is a feature of internationalization worldwide, and thus we should not be too critical of Japan's emphasis on the role of English in this process. English has played a historically important role in Japan, from the Meiji Restoration in 1863 to today's global business pressures. Certainly, the focus of English's role as the lingua franca of education and research fits in with current thinking of English as a Lingua Franca research, which sees ownership of English by a global community. Analysis of policy implementation indicated a positioning of English as an important tool for Japanese graduates to integrate in a global field, including its use as a lingua franca in domestic educational settings. Once again, this seemed to be positioned very differently from Global 30 Project policy, which placed ownership and use of English with the international student body and foreign faculty.

In terms of the criticisms of the dualism or Othering (Hashimoto 2013), which sparked criticism of the Global 30 Project the TGUP also seems to have lessened the rhetorical divide between Japanese and "Others." Horiguchi et al. (2015: 5) have argued that "The English language represents the historical ambivalence of Japan towards the cultural Other, English is both desirable and threatening ... [particularly] if acquired in a controlled manner so that 'Japaneseness' is not obscured." Certainly, historical policy dating back to kokusaika in the 1980 s sought to internationalize Japanese society while maintaining Japanese nationalism. This sentiment holds true today, as it has been observed, "Japanese internationalisation has a unique connotation which is related to developing students' skills and ability to engage with other nations for promoting Japan and Japanese in the world" (Hamid et al. 2013: 7).

Such a unique idea was certainly present in the implementation of the Global 30 Project with the creation of EMI courses for "Others," quite separate from the EMI movements aimed at the domestic market for "Japanese" students, which have been occurring outside of these policy initiatives. In contrast, TGUP seems to emphasize the development of EMI courses for both the domestic and international student body. It also did not make a distinction between international foreign faculty and Japanese faculty with international research experience, allowing both types of faculty to be included in international faculty targets, further circumventing the issue of "Othering" in this policy.

\section{Implications and conclusion}

The findings of this study have implications for higher education policy throughout the East Asian region, where similar movements in language planning have been observed. It has been noted, for example, that universities throughout East Asia have been integrating English 
language into new and existing university programs for the purpose of facilitating international student mobility, as well as to "meet domestic demand for an internationalization at home' experience" (Galloway and Rose 2015: 232). Thus, the exploration of policy in Japanese higher education could potentially provide an illustrative example of failures and success in internationalization and language planning for countries where similar initiatives are emerging. The TGUP allows universities to internationalize via their own initiatives in uniquely different ways, playing to the strengths of their existing programs. This variation might then provide numerous models of internationalization, which from a research perspective would be valuable in terms of exploring the successes and failures of each university's approach.

A further implication of the study presented here is a need to explore this internationalization policy in practice. As the TGUP is in the early stages of implementation, it is impossible to fully evaluate how policy is translated in terms of curriculum and classroom practices. Currently, the top-down project documents examined here only offer an idealized version of policy implementation from the participant universities. Much of the wording in the publically available documents was likely taken from proposal documentation sent to MEXT and therefore mirrors the TGUP objectives. Field research at the TGUP is an essential next step in order to examine how these objectives manifest into actions.

An important limitation to this study was the decision to only analyze documents provided in English. While the decision is justified in the fact that English-language documents are published for international readership, it may have created a bias toward the possibly overvalued focus on EMI in the internationalization of Japan's higher education. Such a bias may have been caused by possible translation discrepancies or errors from the original Japanese or simply by the fact that the documents were published in English. A future study, which analyzes Japanese versions of these documents, would help to establish whether discrepancies exist and whether such a bias is evident.

Nevertheless, data from project documentation indicates that TGUP policy has positioned internationalization in Japanese higher education in European terms (see Frølich 2006, Tange and Jensen 2012), with aims to create global human resources and to globalize the academic environment of Japanese universities. TGUP has also prioritized the integration of the Japanese student body at the 37 universities into a global market, highlighting the importance of language education to achieve this goal. While maintaining the "Englishization equals internationalization" ideology that is pervasive in higher education worldwide, the TGUP may offer a more positive opportunity for universities to internationalize by allowing each university to follow their own independent initiatives and foster stronger ties via internationalization of faculty, student body, and research practices. Huge initiatives such as the TGUP are certainly worthy of research attention and further investigation, as they are part of a larger developing trend that has seen the growth of English language in many universities in non-Anglophone contexts.

Open Access This article is distributed under the terms of the Creative Commons Attribution 4.0 International License (http://creativecommons.org/licenses/by/4.0/), which permits unrestricted use, distribution, and reproduction in any medium, provided you give appropriate credit to the original author(s) and the source, provide a link to the Creative Commons license, and indicate if changes were made. 


\section{References}

Ball, P., \& Lindsay, D. (2013). Language demands and support for English-medium instruction in tertiary education. Learning from a specific context. In A. Doiz, D. Lasagabaster, \& J. M. Sierra (Eds.), Englishmedium instruction at universities. Global challenges (pp. 44-63). Bristol: Multilingual Matters.

Brenn-White, M., \& Faethe, E. (2013). English-taught master's programs in Europe: a 2013 update. New York: Institute of International Education.

Brown, L., \& Holloway, I. (2008). The adjustment journey of international postgraduate students at an English university: an ethnographic study. Journal of Research in International Education, 7(2), 232-249.

Burgess, C., Gibson, I., Klaphake, J., \& Selzer, M. (2010). The "Global 30" Project and Japanese Higher Education Reform: an example of a "closing in" or an "opening up"? Globalisation, Societies and Education, 8(4), 461-475.

Butler, Y. G., \& Iino, M. (2005). Current Japanese reforms in English language education: the 2003 "action plan". Language Policy, 4(1), 25-45.

Delgado-Márquez, B. L., Ángeles Escudero-Torres, M., \& Hurtado-Torres, N. E. (2013). Being highly internationalised strengthens your reputation: an empirical investigation of top higher education institutions. Higher Education, 66(5), 619-633.

Doiz, A., Lasagabaster, D., \& Sierra, J. M. (2013). Introduction. In A. Doiz, D. Lasagabaster, \& J. M. Sierra (Eds.), English-medium instruction at universities. Global challenges (pp. xvii-xvi1). Bristol: Multilingual Matters.

Echevarria, J. A., \& Graves, A. (2006). Sheltered content instruction: teaching English language learners with diverse abilities (3rd ed.). Boston, MA: Allyn \& Bacon.

Forbes-Mewett, H., \& Nyland, C. (2012). Funding international student support services: tension and power in the university. Higher Education, 65(2), 181-192.

Frølich, N. (2006). Still academic and national-internationalisation in Norwegian research and higher education. Higher Education, 52(3), 405-420.

Galloway, N., \& Rose, H. (2015). Introducing Global Englishes. Abingdon: Routledge.

Hamid, M. O., Nguyen, H. T. M., \& Baldauf Jr., R. B. (2013). Medium of instruction in Asia: context, processes and outcomes. Current Issues in Language Planning, 14(1), 1-15.

Hashimoto, K. (2013). "English-only", but not a medium-of-instruction policy: the Japanese way of internationalising education for both domestic and overseas students. Current Issues in Language Planning, 14(1), 16-33.

Horiguchi, S., Imoto, Y., \& Poole, G. S. (2015). Foreign language education in Japan: exploring qualitative approaches. Rotterdam: Sense.

Imoto, Y. (2013). Japan: internationalisation in education and the problem of introspective youth. In P. T. J. Hseih (Ed.), Education in East Asia (pp. 127-152). London: Bloomsbury.

Iwabuchi, K. (2005). Multinationalizing the multicultural: commodification of 'ordinary foreign residents' in a Japanese TV talk show. Japanese Studies: Bulletin of the Japanese Studies Association of Australia, 25(2), $103-118$.

Jenkins, J. (2011). Accommodating (to) ELF in the international university. Journal of Pragmatics, 43(4), 926936.

Kirkpatrick, A. (2011). English as an Asian lingua franca and the multilingual model of ELT. Language Teaching, 44(2), 212-224.

Knight, J. (2003). Updated internationalisation definition. International Higher Education, 33, 223.

Kuckartz, U. (2014). Qualitative text analysis: a guide to methods, practice \& using software. London: Sage.

Lincicome, M. (2005). Globalization, education, and the politics of identity in the Asia-Pacific. Critical Asian Studies, 37(2), 179-208.

Mayring, P. (2000). Qualitative Content Analysis. Forum: Qualitative Social Research, 1(2). Retrieved from http://www.qualitative-research.net/index.php/fqs/article/view/1089

McKinley, J. (2017). Making the EFL to ELF transition at a global traction university. In A. Bradford \& H. Brown (Eds.), English-medium instruction at universities in Japan: policy, challenges and outcomes (in press). Bristol: Multilingual Matters.

MEXT (2012). Selection for the FY2012 Re-Inventing Japan Project. Retrieved from http:/www.mext.go. jp/en/policy/education/highered/title02/detail02/sdetail02/sdetail02/1374092.htm.

MEXT (2014). Selection for the FY2014 Top Global University Project. Retrieved from http://docplayer. net/16379288-Selection-for-the-fy-2014-top-global-university-project-we-hereby-announce-the-selectionof-universities-for-the-top-global-university-project.html.

Montgomery, S. L. (2013). Does science need a global language?: English and the future of research. Chicago: University of Chicago Press. 
Phan, L. H. (2013). Issues surrounding English, the internationalization of higher education and national identity in Asia: a focus on Japan. Critical Studies in Education, 54, 160-175.

Phillipson, R. (2008). Lingua franca or lingua frankensteinia? English in European integration and globalisation. World Englishes, 27(2), 250-267.

Schreier, M. (2014). Qualitative content analysis. In U. Flick (Ed.), The SAGE handbook of qualitative data analysis (pp. 170-183). London: Sage.

Seargeant, P. (Ed.). (2011). English in Japan in the era of globalization. New York: Palgrave Macmillan.

Seargeant, P. (2008). Ideologies of English in Japan: the perspective of policy and pedagogy. Language Policy, $7(2), 121-142$.

Selzer, M., \& Gibson, I. (2009). Preparing Japanese students for English-medium instruction in international studies: methodology and practice in the IIIS international public service program. Ritsumeikan Journal of International Studies, 22(1), 127-140.

Shen, W. (2008). International student migration: the case of Chinese "sea-turtles". In D. Epstein, R. Boden, R. Deem, R. Fazal, \& S. Wright (Eds.), World yearbook of education 2008: geographies of knowledge, geometries of power: framing the future of higher education (pp. 211-232). New York: Routledge.

Shimomura, H. (2013). Making Japanese higher education more international. The Japan Times, B1. Retrieved from http://info.japantimes.co.jp/ads/pdf/20130902_global 30_universities.pdf.

Singh, M. (2005). Enabling transnational learning communities: policies, pedagogies and politics of educational power. In P. Ninnes \& M. Hellstén (Eds.), Internationalizing higher education (pp. 9-36). Dordrecht: Springer.

Song, M. M., \& Tai, H. H. (2007). Taiwan's Responses to Globalisation: internationalisation and questing for world class universities. Asia Pacific Journal of Education, 27(3), 323-340.

Sugimura, M. (2015). The mobility of international students and higher education policies in Japan. The Gakushuin Journal of International Studies, 2, Retrieved from http://glim-re.glim.gakushuin.ac. jp/bitstream/10959/3710/1/gjis_2_1_19.pdf.

Tange, H., \& Jensen, I. (2012). Good teachers and deviant learners? The meeting of practices in university level international education. Journal of Research in International Education, 11(2), 181-193.

Taylor, V. (2014). A Japan that can say 'yes'. East Asia Forum, 6(3), 38-40.

Wachter, B., \& Maiworm, F. (2008). English-taught programmes in European higher education. Bonn: Lemmens.

Wilkinson, R. (2013). English-medium instruction at a Dutch university: challenges and pitfalls. In A. Doiz, D. Lasagabaster, \& J. M. Sierra (Eds.), English-medium instruction at universities. Global challenges (pp. 326). Bristol: Multilingual Matters.

Yamada, Y. (2003). Gengo seisaku toshiteno Nihon no eigokyōiku [Japan's English language education as language policy]. Hiroshima, Japan: Keisuisha. 